\title{
EFFECT OF SOYA AND WHEY PROTEINS ON THE SENSORY AND PHYSICOCHEMICAL PROPERTIES OF SET YOGHURT
}

\author{
El-Abd, M. M. ${ }^{1}$; E. M. Hamad ${ }^{1}$ Jihan M. Kassem ${ }^{2}$ \\ Eman T. A. Yousef ${ }^{3}$ and Rasha N. M. Tawfik ${ }^{3}$ \\ ${ }^{1,2}$ Dairy sciences department, Faculty of Agriculture, Cairo \\ University. \\ ${ }^{3}$ Dairy sciences department, National Research Centre. \\ 4,5 Dairy sciences department, Food Technology Research \\ Institute, Agriculture Research Centre.
}

\begin{abstract}
Recently, a focus on the utilization of whey and soya proteins has been receiving significant attention due to their nutritional value and their potential to enhance the functional characteristics of the dairy products. Set yoghurt was manufactured from standardized ( $4 \%$ fat) buffalo milk alone (control), or fortified with whey protein concentrate (WPC), soya protein concentrate (SPC) or their combination (MIX) and stored at $5 \pm 2{ }^{\circ} \mathrm{C}$ for 10 days. Sensory properties of the resultant yoghurt were evaluated one day after manufacturing. All treatments were analyzed when fresh and during storage period for $\mathrm{pH}$-value, titratable acidity $(\mathrm{TA})$ and syneresis. The $\mathrm{pH}$ values and titratable acidity $(\mathrm{TA})$ of yoghurt samples showed that both soya and whey proteins did not alter the rate of acid production in yoghurt. Acidity of samples treated with WPC during storage was significantly $(\mathrm{P}<0.05)$ higher, compared to control. Also, the addition of whey proteins and soya proteins or their combination resulted in reduction in the syneresis of yoghurt samples by about $17-25 \%$, when compared with control at zero time. Fortification with soya proteins lowered appearance, taste and odor scores by 25,37 and $35 \%$, respectively, compared with the control. This negative effect of soya proteins on the sensory properties of yoghurt (SPC treatment) was improved when combined with whey protein in the MIX treatment. Therefore, it is recommended to add whey proteins to improve sensory and syneresis properties of soya yoghurt.
\end{abstract}

Keywords: Yoghurt, Soy Proteins, Whey proteins, Sensory Evaluation, Syneresis.

\section{INTRODUCTION}

It is well known, that soybean is an important source of plant proteins. It has several unique properties, such as high nutritional value, good functional properties in food technology and low cost (Walsh et al., 2010). It received a significant attention from not only the food industry, but also the consumers. Therefore, its demand to be used as a replacer of animal proteins in different food and dairy products have been increased.

Nowadays, the demand of soya-based yoghurt, or soya yoghurt, has increased in the marketplace, especially, among vegetarians and consumers who prefer plant-origin foods. The components of soya are reported to be useful to human health because of their potential to reduce the risk of cancer, heart disease, osteoporosis and high blood cholesterol levels (Kovalenko and Briggs, 2002). Due to its beany smell and astringent taste, which considered 
as off-flavor, soya yoghurt is not widely accepted by consumers. There are several studies have been conducted to produce soya yoghurt with acceptable flavor (Yang and $\mathrm{Li}, 2010$ ). Earlier study found that fortification of low fat yoghurt with soya proteins (from 1.0 to $4.0 \%$ level) can produce more acceptable yoghurts (Zanhi and Jideani, 2012).

Not only soya proteins, but also whey proteins have been added to yoghurt to improve its characteristics. Whey proteins; which is produced as a by-product of the cheese manufacture; represents about $20 \%$ of milk proteins. In addition to their high potential nutritional value, they also show an improvement in the functional properties of food and dairy products that in turn excessively modify the product quality attributes (Eissa and Khan, 2006). Many studies have been carried out in an attempt to improve the physical, textural and rheological properties of yoghurt fortified with whey proteins (Cheng et al., 2000; Gonzalez-Martinez et al., 2002; Aziznia et al., 2008; Landge, 2009).

Sensory properties have a large effect on the consumers' acceptability of any new products. Thus, the aim of the present study was to evaluate the effect of addition of soya, whey proteins or their combination on the sensory and physicochemical properties of yoghurt made from buffalo milk.

\section{MATERIALS AND METHODS}

Fresh buffalo's milk was obtained from the farm of Fac. of Agric., Cairo Univ., Egypt. Starter culture (Lactobacillus delbrueckii ssp. bulgaricus and Streptococcus thermophilus) was obtained from the stock cultures of Dairy Microbiology Lab., Fac. of Agric., Cairo Univ., Egypt. Whey protein concentrate (WPC) 80\%- Fedex Co., USA- was purchased from Light Food Co., Cairo, Egypt. Soya protein concentrate (SPC) $60 \%$ - was purchased from Nantong Sun - Green Bio - Tech. Co., China.

Fresh buffalo's milk was standardized to $\sim 4.0 \%$ fat using skim milk. The modified milk was heated to $85^{\circ} \mathrm{C}$ for $10 \mathrm{~min}$ and cooled to $42^{\circ} \mathrm{C}$. Then divided into 4 equal portions. The first portion was set as a control without any addition. The second and third portions were fortified with either whey proteins (WPC) or soya proteins (SPC). The last portion was fortified with a mixture of both of them (MIX). Depending on the previous studies (Zanhi and Jideani (2012) \& Delikanli and Ozcan, 2014), who found that both whey and soya proteins could be added with different levels. In the present study, the level of addition of both whey and soya proteins had been chosen to be $2.26 \mathrm{gm} / 100 \mathrm{ml}$. All yoghurt milk were inoculated with $2.0 \%$ of mixed starter culture (1:1), dispensed into plastic cups $(100 \mathrm{ml})$ and incubated at $42^{\circ} \mathrm{C}$ until coagulation was formed (Barrantes et al., 1994). The yoghurt samples were stored at $5 \pm 2^{\circ} \mathrm{C}$ and analyzed one day after manufacture as fresh samples (zero time) and after 3, 7 and 10 days of storage. Three replicates were analyzed from each treatment.

The $\mathrm{pH}$ value was measured in yoghurt samples using a digital $\mathrm{pH}$ meter PHM92 (MeterLab TM, Radiometer Analytical S.A., France). Titratable acidity of yoghurt samples was measured as described by Ling (1963). For 
syneresis measurements, an amount of $25 \mathrm{~g}$ of the yoghurt sample was placed into centrifuge tube and centrifuged at $1290 \mathrm{xg}$ for $20 \mathrm{~min}$ (Sigma Laborzentri Fugen, 2 K15, Germany) as described by Aguilera \& Kessler (1989). The weight fraction of the supernatant liquid was used as an index of whey syneresis ( $\mathrm{ml} / 100 \mathrm{~g}$ yoghurt).

For sensory evaluation, the set yoghurt samples were assessed by a panel (10 persons) from the Department Staff. The assessed properties were: Appearance (20 points), body and texture (30 points), taste (30 Points) and odor (20 points) with a total acceptance of 100 points.

Data were statistically analyzed by one-way ANOVA using general linear model of SPSS, and significant differences $(P \leq 0.05)$ between treatments were determined by Tukey test (SPSS software, ver. 16.0, SPSS Inc., USA, 2001).

\section{RESULTS AND DISCUSSION}

Table (1) showed some chemical and physiochemical properties of yoghurt fortified with whey proteins, soya proteins or their mixture. As it could be noticed from $\mathrm{pH}$-values, there was no significant difference among all yoghurt samples $(\mathrm{P}>0.05)$. The $\mathrm{pH}$-values showed a gradual reduction during storage period in all yoghurt samples. Opposite trend was found in (TA) of all yoghurt samples, but there were also no significant difference between all samples, except that fortified with WPC. These results of $\mathrm{pH}$-values and titratable acidity(TA) of yoghurt samples showed that both soy and whey proteins did not alter the rate acid development in yoghurt by the starter culture. These results are in agreement with those found by Zanhi and Jideani (2012), who found that fortification of yoghurt with soya protein did not affect $\mathrm{pH}$-value or TA of yoghurt. On the other hand, it could be observed that the acidity of WPC samples during storage was significantly $(\mathrm{P}<0.05)$ higher $(0.75 \pm 0.01$ to $0.72 \pm 0.02 \%$, when compared with control $(0.59 \pm 0.01$ to $0.60 \pm 0.02 \%$. This increment in the titratable acidity of WPC yoghurt might be attributed to the increase in the ratio of citrates and phosphates, when concentration of milk solids increased as a result of the addition of whey proteins (Yeganehzad et al., 2007).

The results of syneresis are illustrated in Table (1). Addition of whey proteins, soya proteins or their combination reduced the syneresis of yoghurt samples by about $17-25 \%$, when compared with control yoghurt at zero time. In contrast, all yoghurt treatments showed an increment in syneresis during storage, but WPC, SPC and MIX still showed lower values than control yoghurt. This could imply that the addition of soya, whey proteins or their combination resulted in better absorption of free water within the yoghurt matrix and to decrease syneresis (Cais-Sokolinska et al., 2002). Also, it was cleared that whey proteins was better than soya proteins in holding free water, in which WPC treatment gave less syneresis during storage. This finding was attributed to the reduction in the ratios of casein to whey proteins that increased the gel strength of the resultant yoghurt and reduced drainage of whey (Puvanenthiran et al., 2002). Similarly, soya proteins showed less 
effectiveness in binding free water molecules in previous study (Osundahunsi et al., 2007). The ability of the added proteins to reduce syneresis might indicate a shift in the structure of the resultant yoghurt from compact structure to larger aggregates with casein micelles that give a more rigid gel structure (Zanhi and Jideani, 2012).

Table (1): Effect of addition of soya and whey proteins on the $\mathrm{pH}$, titratable acidity (TA), total solids (TS) and syneresis of set yoghurt.

\begin{tabular}{|l|c|c|c|c|}
\hline \multirow{2}{*}{ Treatment } & \multirow{2}{*}{ Fresh } & \multicolumn{3}{|c|}{ Storage (days) } \\
\cline { 3 - 5 } & & $\mathbf{5}$ & $\mathbf{7}$ & $\mathbf{1 0}$ \\
\hline & \multicolumn{5}{|c|}{$\mathrm{pH}-$ value } \\
\hline Control & $4.97 \pm 0.06^{\mathrm{A}}$ & $4.57 \pm 0.06^{\mathrm{B}}$ & $4.37 \pm 0.06^{\mathrm{CDE}}$ & $4.27 \pm 0.06^{\mathrm{DE}}$ \\
\hline WPC & $4.90 \pm 0.10^{\mathrm{A}}$ & $4.37 \pm 0.06^{\mathrm{CDE}}$ & $4.27 \pm 0.06^{\mathrm{DE}}$ & $4.27 \pm 0.06^{\mathrm{DE}}$ \\
\hline SPC & $4.83 \pm 0.06^{\mathrm{A}}$ & $4.30 \pm 0.10^{\mathrm{CDE}}$ & $4.27 \pm 0.06^{\mathrm{DE}}$ & $4.23 \pm 0.06^{\mathrm{E}}$ \\
\hline MIX & $4.93 \pm 0.06^{\mathrm{A}}$ & $4.43 \pm 0.06^{\mathrm{BCD}}$ & $4.33 \pm 0.06^{\mathrm{CDE}}$ & $4.33 \pm 0.06^{\mathrm{CDE}}$ \\
\hline \multicolumn{5}{|c|}{ Titratable acidity $(\%)$} \\
\hline Control & $0.54 \pm 0.01^{\mathrm{F}}$ & $0.59 \pm 0.01^{\mathrm{EF}}$ & $0.62 \pm 0.01^{\mathrm{CDEF}}$ & $0.69 \pm 0.02^{\mathrm{ABCD}}$ \\
\hline WPC & $0.63 \pm 0.02^{\mathrm{CDEF}}$ & $0.75 \pm 0.01^{\mathrm{A}}$ & $0.70 \pm 0.02^{\mathrm{ABC}}$ & $0.72 \pm 0.02^{\mathrm{AB}}$ \\
\hline SPC & $0.63 \pm 0.01^{\mathrm{BCDEF}}$ & $0.68 \pm 0.01^{\mathrm{ABCD}}$ & $0.67 \pm 0.01^{\mathrm{ABCD}}$ & $0.67 \pm 0.01^{\mathrm{ABCDE}}$ \\
\hline Mix & $0.59 \pm 0.02^{\mathrm{EF}}$ & $0.67 \pm 0.01^{\mathrm{ABCD}}$ & $0.67 \pm 0.01^{\mathrm{ABCD}}$ & $0.69 \pm 0.01^{\mathrm{ABCD}}$ \\
\hline \multicolumn{5}{|c|}{ Syneresis $(\mathrm{ml})$} \\
\hline Control & $8.00 \pm 1.00^{\mathrm{AB}}$ & $8.33 \pm 2.08^{\mathrm{AB}}$ & $9.00 \pm 1.00^{\mathrm{AB}}$ & $11.67 \pm 1.53^{\mathrm{A}}$ \\
\hline WPC & $6.00 \pm 1.00^{\mathrm{B}}$ & $6.00 \pm 2.65^{\mathrm{B}}$ & $7.00 \pm 2.00^{\mathrm{B}}$ & $8.67 \pm 0.58^{\mathrm{AB}}$ \\
\hline SPC & $6.33 \pm 1.53^{\mathrm{B}}$ & $7.67 \pm 2.52^{\mathrm{AB}}$ & $7.67 \pm 1.53^{\mathrm{AB}}$ & $8.33 \pm 1.15^{\mathrm{AB}}$ \\
\hline MIX & $6.67 \pm 1.53^{\mathrm{AB}}$ & $7.00 \pm 2.65^{\mathrm{AB}}$ & $8.33 \pm 1.15^{\mathrm{AB}}$ & $8.67 \pm 0.58^{\mathrm{AB}}$ \\
\hline
\end{tabular}

Values are means \pm standard deviation.

Means with different superscripts are significantly differ $(P<0.05)$.

Sensory evaluation of WPC, SPC and MIX yoghurts were elucidated in Table (2) and Fig. (1). It could be observed that the highest sensory scores for appearance, taste and odor were given to MIX yoghurt treatments. While, the lowest sensory scores for appearance, taste and odor were given to SPC yoghurt treatments. Fortification with soya proteins lowered appearance, taste and odor by 25,37 and $35 \%$, respectively, compared with control. A beany smell and astringent taste was noticed in yoghurt containing soya proteins which affected negatively the flavor (taste and odor) acceptability of SPC yoghurt. This astringent taste or off-flavor which is normally associated with soy foods could be due to the interaction between polyphenolics from soy with mucoprotein in mouth (Rehman et al., 2007). Therefore, it is recommended to extract phenolics from soy before preparing soy protein concentrate when added to yoghurt (Zanhi and Jideani, 2012). Previous report showed also that addition of whey proteins to yoghurt developed better physical and sensory properties (Delikanli \& Ozcan, 2014). 
Table (2): Effect of adding soya and whey proteins on the sensory evaluation of set yoghurt.

\begin{tabular}{|l|c|c|c|c|}
\hline Treatment & $\begin{array}{c}\text { Appearance } \\
(\mathbf{2 0})\end{array}$ & $\begin{array}{c}\text { Body \& Texture } \\
\mathbf{( 3 0 )}\end{array}$ & $\begin{array}{c}\text { Taste } \\
(\mathbf{3 0})\end{array}$ & $\begin{array}{c}\text { Odor } \\
(\mathbf{2 0})\end{array}$ \\
\hline Control & $17.40 \pm 1.35^{\mathrm{A}}$ & $26.00 \pm 1.70^{\mathrm{A}}$ & $27.20 \pm 1.40^{\mathrm{A}}$ & $18.60 \pm 1.07^{\mathrm{A}}$ \\
\hline WPC & $17.70 \pm 2.06^{\mathrm{A}}$ & $26.10 \pm 2.38^{\mathrm{A}}$ & $27.00 \pm 2.16^{\mathrm{A}}$ & $18.40 \pm 1.71^{\mathrm{A}}$ \\
\hline SPC & $13.10 \pm 2.69^{\mathrm{B}}$ & $26.30 \pm 1.42^{\mathrm{A}}$ & $17.20 \pm 4.89^{\mathrm{B}}$ & $12.00 \pm 3.43^{\mathrm{B}}$ \\
\hline MIX & $18.80 \pm 1.48^{\mathrm{A}}$ & $28.10 \pm 1.29^{\mathrm{A}}$ & $28.00 \pm 1.33^{\mathrm{A}}$ & $18.90 \pm 1.10^{\mathrm{A}}$ \\
\hline
\end{tabular}

Values are means \pm standard deviation.

Means with different superscripts are significantly differ $(P<0.05)$.

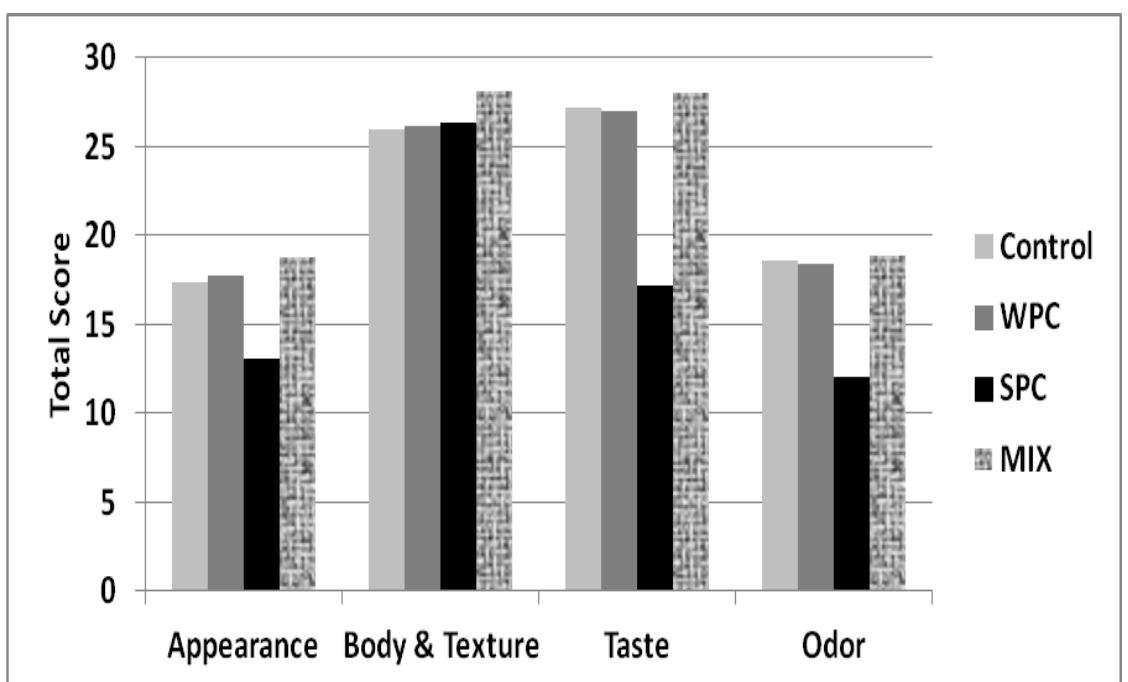

Figure (1): Effect of adding soya and whey proteins on the sensory evaluation of set yoghurt

\section{CONCLUSION}

Production of soya yoghurt had been showed minimal improvement in syneresis and also showed unacceptable flavor. Making a mixture of whey proteins and soy proteins resulted in a remarkable improvement in sensory and functional properties of yoghurt product.

\section{REFERENCES}

AOAC,(2007). Association of Official Analytical Chemists. Official Methods of Analysis. $20^{\text {th }}$ Ed., Gaithersburg, M D, USA.

Aziznia S.; Khosrowshahi A.; Madadlou A. and Rahimi J. (2008). Whey protein concentrate and gum tragacanth as fat replacers in nonfat yoghurt: chemical, physical, and microstructural properties. Journal of Dairy Science, 91: 2545-2552. 
Barrantes et al., (1994). Yoghurt- Science and Technology, Second edition.

Cais-Sokolinska D.; Pikul J. and Dankow R. (2002). Quality and stability of the natural yoghurt produced from milk condensed with whey protein concentrate. Electronic J. Polish Agric. Univ. 5:1505-1518.

Cheng L. J.; Augustin M. A. and Clarke P. T. (2000). Yoghurts from skim milk - whey protein concentrate blends. Australian Journal of Dairy Technology, 55; 110.

Delikanli, B. and Ozcan, T. (2014). "Effects of various whey proteins on the physicochemical and textural properties of set type nonfat yoghurt". International Journal of Dairy Technology, 67:495-503.

Eissa, A. S. and Khan, S. A. (2006). "Modulation of hydrophobic interactions in denatured whey proteins by transglutaminase enzyme." Food Hydrocolloids 20: 543-547.

Gonzalez-Martinez C.; Becerra M.; Chafer M.; Albors A.; Carot J. M. and Chiralt A. (2002). Influence of substituting milk for whey powderon yoghurt quality. Trends in Food Science and Technology, 13: 334-340.

Kovalenko I.V. and Briggs J.L. (2002). Texture characterization of soy-based yoghurt by the vane method. J. Texture Stud., 33: 105-1 18.

Landge V. L. (2009). Quality of yoghurt supplemented with whey protein concentrate and effects of whey protein denaturation. Master's Thesis. Faculty of Food Sciences, Kansas State University, Manhattan, Kansas.

Ling, E. R. (1963). A text book of dairy chemistry Chapman \& Hall (eds.), London.

Osundahunsi O. F.; Amosu D. and Ifesan B. O. T. (2007). Quality evaluation and acceptability of soy yoghurt with different colors and fruit flavors. J. Food Technol. 2:276-280.

Puvanenthiran A.; Williams R. P. W. and Augustin M. A. (2002). Structure and viscoelastic properties of set yoghurt with altered casein to whey protein ratios. International Dairy Journal, 12: 383-391.

Rehman S.; Navaz H.; Ahmad M. M.; Hussain S.; Murtaza S. and Shahid S. H. (2007). Physico-chemical and sensory evaluation of ready to drink soy-cow milk blend. Pak. J. Nutr. 6:283-285.

Walsh H.; Ross J.; Hendricks G. and Guo M. (2010). Physico-chemical properties, probiotics survivability, microstructure, and acceptability of a yoghurt-like symbiotic oats-based product using pre-polymerized whey protein as a gelation agent. J. Food Sci. 75(5):327-337.

Yang M. and Li L. (2010). "Physicochemical, Textural and Sensory Characteristics of Probiotic Soy Yoghurt Prepared from Germinated Soybean". Food Technol. Biotechnol., 48 (4) 490-496.

Yeganehzad S.; Mazaheri-Tehrani M. and Shahidi F. (2007). "Studying microbial, physiochemical and sensory properties of directly concentrated probiotic yoghurt". African Journal Agricultural Research 2366-369.

Zanhi, N. K. and Jideani, I. A. (2012). "Physico-chemical and sensory qualities of soy and milk solids fortified low fat yoghurt" African J Agri Res, 7(38): 5336-5343. 


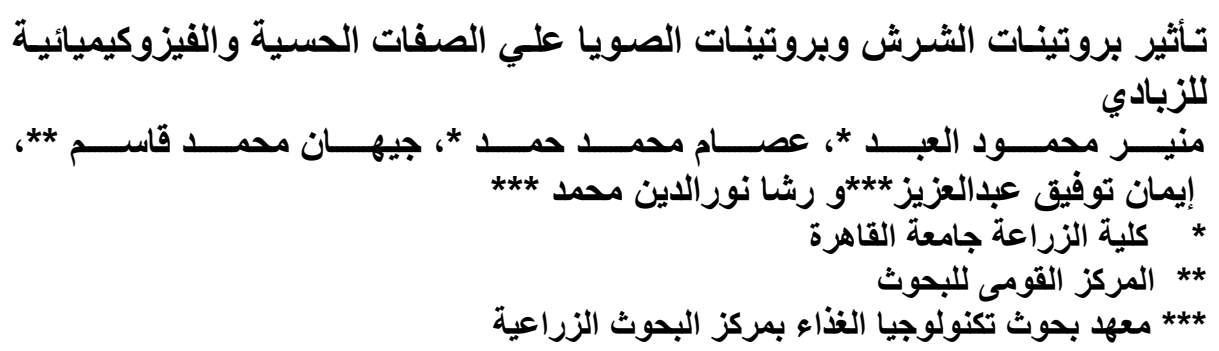

شهدت الأونة الأخيرة تعدد الدراسات التي تتناولت زيادة استخدام بروتينات الشرش وبرات وبروتينات الصويا

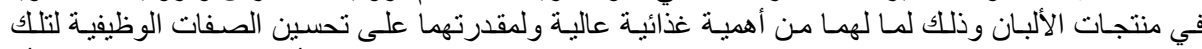

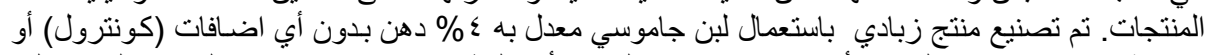

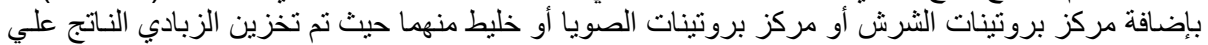

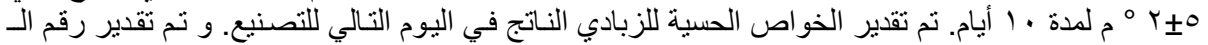

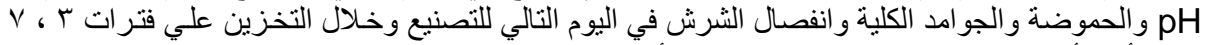

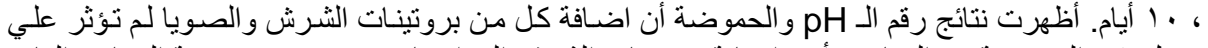

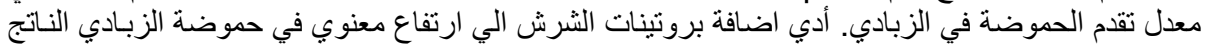

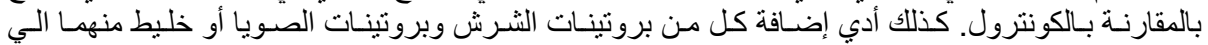

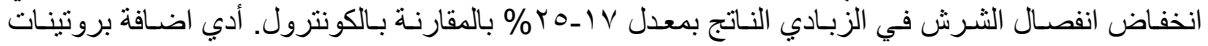

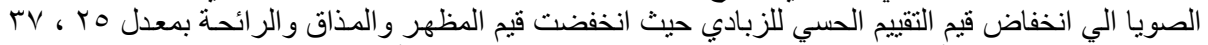

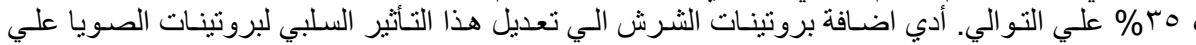

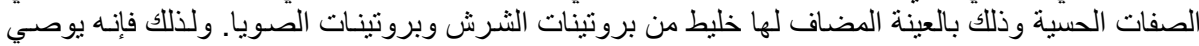

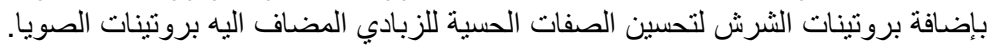

